\title{
Improving Teachers' Competence and Students' Character Through Lesson Study
}

\author{
Suherman \\ Universitas Tadulako \\ Palu, Indonesia \\ syfa_herman@yahoo.com
}

\author{
Supriadi \\ Universitas Tadulako \\ Palu, Indonesia
}

\begin{abstract}
Lesson study (LS) at senior and junior high schools (SMAN 1, SMPN 1 and SMPN 2 Palu) in Palu have been implementing since 2011 until 2016. It was supported by LS Grant of Department of Mathematics and Natural Sciences Education (PMIPA) FKIP Tadulako University, Fundamental Grant and Community Service Grant. The purpose of this activity was to improve the competence of teachers to implement quality learning and to form a positive character in each student. The method used was the character identification of students which cover attitude, cognitive, and skill. Training teachers in implementing the learning that patterned in LS started with a plan, do, and see to be applied to the implementation of learning. Furthermore, the other activity was mentoring teachers who have been trained. The results obtained were; in 2011 until 2012, all teachers of Mathematics and Science at the partner school still studied and reviewed the patterns of LS. In 2013, it was identified that the attitudes and skills of SMAN 1 Palu students of science class required attention. When a student in that school was given 2 times of LS learning, then there was a positive impact on the development of student character. In 2014, LS was performed in SMPN 1 Palu to all fields of study. Then all teachers were instructed to give LS continues as the service programs. Every Saturday all teachers to continue to implement LS, especially subjects that include the national exam (UN). As the result, students of SMPN 1 Palu dominated the top 10 rankings of UN in the province. In conclusion, it can be said that LS will provide better results to teachers and students if $\mathrm{LS}$ applies continuous and sustainable.
\end{abstract}

\section{Keywords-lesson study; competence; character; student}

\section{INTRODUCTION}

Expansion Program of Lesson Study (LS) encourages educators to improve the quality of learning as well as the quality of learning outcomes of students. Therefore, it is an effort of improving the quality of education. Improving the quality of learning outcomes include knowledge, attitude, and skill. This is intended to encourage students to be smart, intelligent, comprehensive, and competitive. The results of the study [1] indicate that in shaping intelligence of students, $1 / 3$ comes from the cognitive part and $2 / 3$ is from skill. However, it is not enough to form students' personality which has comprehensive and competitive power. Personality can be formed through positive attitudes. Therefore, the implementation phase of LS with complex learning design is intended to establish and foster practice for each student who is smart and intelligent, which results in meaningful learning.
Lesson Study is not an approach, method, or strategy for learning, but it is a model of professional guidance for educators through collaborative learning assessment and it is sustained through the principle of collegiality, mutual learning and community learning [2], [3]. Teachers need to be equipped LS in order to make teachers more professional and competent, especially in their field. Therefore, the implementation of LS is carried out jointly by teachers and colleagues to form a learning community at schools based on the principle of LS which go through Plan, Do, See, and Redesign. LS has been shown to increase professional competence of teachers such as in Japan, used \pm 130 years ago in a sustainable and continuous process [3], [4]. This brings about professional teachers, which finally can improve the quality of education at the top in the world ranking.

Plan (instructional design) was carried out in collaboration between teacher models and colleagues. This means that both teachers and peer models are equally responsible for the implementation of learning design implemented by the model teacher. In Plan, both material and instructional details were prepared. All those involved in the Plan can provide a valuable learning experience to create a better plan for the implementation in the open class which becomes better and meaningful [5], [6].

In $D o$ phase, we opened class or went to a class where teacher model teaches and collaborator observed, or not the same ancestor. The main concern is the observer to the implementation of learning activity, creativity, teamwork, discipline, honesty, responsibility, and skills of students. Therefore, based on scenario design learning, teachers must pay attention to all the models of students with the intent of all students are active and understand the learning material. Teachers to perform important role models for the implementation of learning can be successful that all students can work together, be responsible, and skillful in the implementation of learning. At the end of the lesson, the teacher models evaluated the success rate of learning implemented through tests to students. The goal is as bait turning on the quality of learning design arranged in collaboration, and Traffic teachers implement meaningful learning models [3], [5], [6].

Based on the description of each phase of LS, the Lesson Study activities can realize learning "multiple pathways of 
learning" that can improve the quality of the learning process, because: (1). Improving knowledge of teaching materials, (2). Improving knowledge about teaching, (3). Increase capability to observe student, (4). Further strengthen the network of collegiality, (5). Further strengthen the link between the everyday teaching practices with the goal of long-term education, (6). Strengthens motivation and sensitivity, and (7). Improving the quality of lesson plans and the implementation process [3].

Under government regulations No.19 of 2005 on National Education Standards, Chapter IV, Article 19, paragraph 1 states that the learning process in the education unit is held in an interactive, inspiring, fun, challenging, motivating learners to actively participate and provide enough space for the initiative, creativity, and independence according to talents, interests, and physical and psychological development of learners [7]. This suggests that learning an educator is expected to have an approach, strategies, methods, techniques and specific tactics that can create conditions for the class of active learning, innovative, creative, and fun. So, in the end, will be acquired conditions that motivated class, to high activity until obtained satisfactory improvement of learning outcomes [8]. LS can be used as a bridge to climb towards the ideals of the ideal learning process as stated in the National Education Standards.

Accomplishment this, the government seeks to teachers can improve the quality of learning. The effort is to provide training to teachers either training related to the increase of professional competence of teachers and improving the competence of pedagogy (Act No. 14 of 2005). Both of these outcomes are directly related to the teacher's task as described in ministerial regulation of Plan and Sustainable namely: (1) The ability of mastery of the material structure of the concept and mindset of science that supports the subjects was taught as professional competence and (2) the ability to know the characteristics of the students, master learning theory and principles of educational learning, curriculum development, instructional activities to educate, understand and develop competence, communication with students, assessment and evaluation.

Lesson study is a learning activity, in practice, it takes sincerity, patience, creativity, teamwork, innovation, selfreliance, and responsibility both by teachers and students. Demands on each teacher competence and development of each student achievement through learning can be achieved in a sustainable and continuous of LS. Results LS can be realized when done on an ongoing basis, so the character of each student can be turned towards the positive if LS did continuously. As has been explained before, the phase of LS begins with the stage plan. This phase increases professional competence and pedagogic every teacher because every teacher involved always reveal the depth of content suitable for such use pedagogy. In addition to these competencies, also can form personal competence and social competence every teacher, because in the process of learning design all the teachers involved shows arranged good cooperation, and always imagine the condition of the students in the initial state, the state at the time of the learning takes place, and the final state of learning [9].

The implementation stage do/open class can shape positive character traits in students, this stage leads cooperation; to be sent students, self-reliance, discipline, creativity, honesty, innovation, and student responsibility. This character is easy to identify on each student because every student/group observed by observers from the first minute until the lastminute implementation of learning. Similarly, the model teacher always makes attention to the development of student learning which includes cognitive, attitudes, and skills. The positive character development of each student in constant learning implementation patterned with LS. It is possible because model teacher and observer of the circumstances always make attention of each student, and then reflected to be repaired. The main objective of this study is to provide guidance for professional teachers and students develop positive character insane to form an intelligent, comprehensive, and competitive.

\section{METHOD}

The object of this research was junior high school teachers, teachers of chemistry and biology in high school, and high school students in Palu. This study was patterned LS learning and the identification code of Palu city high school students. LS patterned learning, professional competence and pedagogic identify teachers. Identification of competencies (character) students that their positive character development of students after learning by LS. Stages of learning were conducted on the plan, do, see, and redesign. Stages as follows;

- Phase plan, the draft study conducted jointly between the teacher models and peers who the same field, both chemistry, and biology for high school and junior high school science the same field.

- Phase do/open class, the model implemented by teachers and will observe by peers which same field and different field.

- See/Reflection, it will be executed as soon after do the implementation, this stage of discussing the success rate of learning the likely by the model teacher, student activity levels, ease and constraints experienced in the implementation of learning. The thing that needs to be corrected for the next cycle.

- The redesign, this stage did pay attention to learning design back with the recommendations of the reflection. The goal is to make improvements to the learning and improve the success rate of student learning.

Regarding the identification of the character development of students (high school) in Palu, the data obtained through questionnaires before by LS learning implementation and LS patterned after a given learning. The method used was the student's character identification using 
LS learning design which focuses on improving the quality of learning and professional development of teachers.

\section{RESULTS AND DISCUSSION}

This research has identified competencies that students on learning implementation religious attitude core competencies and social attitudes, cognitive core competencies and core competency skills of students. Samples were taken from the Class of IPA (Sciences) SMAN 1 Class II and Class I as the city of Palu. Each school is 30 sheets circulated a questionnaire to the class II IPA and 30 questionnaires' sheet to grade 1 (attitudes and skills). Cognitive being taken of the results of the second semester of the academic year 2012/2013 and 2013/2014 for the subjects of mathematics, physics, chemistry, and biology. The results obtained can be seen in Table I.

TABLE I. ANALYSIS OF COGNITIVE, SKILL, AND ATTITUDES OF THE STUDENTS IN ACADEMIC YEAR OF 2012/2013 AND 2013/2014 (FOR SCIENCES)

\begin{tabular}{|c|c|c|c|c|c|c|c|c|c|}
\hline \multirow{3}{*}{ Cognitive } & Ma & $\mathrm{Ph}$ & $\mathrm{Ch}$ & $\mathrm{Bi}$ & & & & & \\
\cline { 2 - 14 } & 82 & 79, & 79, & 83 & & & & & \\
&, 31 & 15 & 84 &, 86 & & & & & \\
\hline \multirow{3}{*}{ Skill } & $\mathrm{P}$ & $\mathrm{Q}$ & $\mathrm{R}$ & $\mathrm{S}$ & $\mathrm{T}$ & $\mathrm{U}$ & & & \\
\cline { 2 - 13 } & 29, & 22, & 50, & 24, & 28, & 29, & & & \\
& 27 & 21 & 78 & 73 & 72 & 27 & & & \\
\hline \multirow{4}{*}{ Attitude } & $\mathrm{A}$ & $\mathrm{B}$ & $\mathrm{C}$ & $\mathrm{D}$ & $\mathrm{E}$ & $\mathrm{F}$ & $\mathrm{G}$ & $\mathrm{H}$ & $\mathrm{I}$ \\
\hline & 57, & 55, & 56, & 70, & 45, & 64, & 44, & 47, & 76, \\
& 15 & 73 & 65 & 41 & 78 & 51 & 33 & 52 & 58 \\
\hline
\end{tabular}

\begin{tabular}{|c|c|c|c|c|c|c|c|c|c|}
\hline \multirow{2}{*}{ Cognitive } & $\mathrm{Ma}$ & $\mathrm{Ph}$ & $\mathrm{Ch}$ & $\mathrm{Bi}$ & & & & & \\
\hline & & & & & & & & & \\
\hline \multirow{2}{*}{ Skill } & & & & & & & & & \\
\cline { 2 - 12 } & & & & & & & & & \\
\hline \multirow{3}{*}{ Attitude } & $\mathrm{J}$ & $\mathrm{K}$ & $\mathrm{L}$ & $\mathrm{M}$ & $\mathrm{N}$ & $\mathrm{O}$ & $\mathrm{P}$ & $\mathrm{Q}$ & $\mathrm{R}$ \\
\cline { 2 - 10 } & 79, & 26, & 50, & 36, & 55, & 78, & 55, & 33, & 25, \\
& 51 & 21 & 24 & 85 & 76 & 76 & 62 & 98 & 52 \\
\hline
\end{tabular}

Note:

Cognitive Value

$\mathrm{Ma}=$ Mathematics

$\mathrm{Ch}=$ Chemistry

$\mathrm{Ph}=$ Physics

$\mathrm{Bi}=$ Biology

Skill

$\mathrm{P}=$ Observation

$\mathrm{Q}=$ Communication

$\mathrm{S}=$ Classification

$\mathrm{R}=$ Measurement

$=$ Conclusion

Attitude

$\begin{array}{ll}\mathrm{A} & =\text { Religious } \\ \mathrm{B} & =\text { Honesty } \\ \mathrm{C} & =\text { Tolerance } \\ \mathrm{D} & =\text { Discipline } \\ \mathrm{E} & =\text { Hard work } \\ \mathrm{F} & =\text { Creativity } \\ \mathrm{G} & =\text { Independence } \\ \mathrm{H} & =\text { Democration } \\ \mathrm{I} & =\text { Curiosity }\end{array}$

$\mathrm{J}=$ Nationality

$\mathrm{K}$ = Love the Homeland

$\mathrm{L}=$ Appreciate Achievement

$\mathrm{M}$ = Friendly

$\mathrm{N}=$ Love Peace

$\mathrm{O}=$ Like to Read

$\mathrm{P} \quad=$ Environmental Care

$\mathrm{Q}=$ Social Care

$\mathrm{R} \quad=$ Responsibility

Information obtained from Table 1 is for cognitive each subject MIPA (Mathematics, Physics, Chemistry, and
Biology) greater than 75.0. This means that the value of knowledge of students included either. But the values of their science process skills were low. This reflects that the learning process performed by the teacher does not require students to high-level thinking. Similarly, evaluation tools used by teachers have a level of analysis and level of difficulty is low. Therefore, there is no form of cleverness to students. A student held back that intelligence can be formed of cognitive skills $33,33 \%$ and $66.67 \%$ [1]. A learning theory suggests that a student can receive a maximum of subject matter from beginning to end is a maximum of $75 \%$. So if teachers only apply taxonomic Bloom cognitive, the level of intelligence of students maximum $33.33 \%$ x $0.75=24.9975$ or 25 points (rounded). This occurred in junior high mathematics Olympiads results throughout Central Sulawesi province, students who received first prize simply get a value of 15 . This fact suggests that when teachers in implementing the learning by simply applying cognitive, it does not form a smart student.

Further information obtained from Table 1 is an average student attitude still low at 53.395. This attitude value gives an indication that there is still much-needed guidance to each student's attitude, one of which is to integrate the learning material with appropriate attitudes that need to be imparted to the students. Integrating attitudes on learning materials required the character of the teacher. Teacher characters are very influential on the formation of student's character (positive attitude). Integration of the characters in the learning material, a chemistry teacher must understand the character of each subject/discussion on chemistry material, as well as the character that needs to be imparted to students through learning. In addition, the teacher always required to better understand the character alignment material (chemicals) that are relevant to the student's character and attitude that needs to be invested [10]. Ref. [1] stated that the planting of the attitude to the students will make smart students, a comprehensive and competitive. Therefore, it is not enough just to make students become smart but must be intelligent, comprehensively, and competitive. Vision Events Calendar no. 16 in 2006, argued that any formal educational institutions (elementary, junior high, high school and university) alumni make an intelligent, comprehensively, and competitive. Therefore, a teacher in implementing the curriculum must understand the core competencies that should be imparted to the students, such as curriculum in 2013 (K13).

Giving of competence for each student in the implementation of learning, it is necessary to integrating learning design materials with the necessary competence, namely be put under the religious attitude core competencies, core competencies of social attitudes, cognitive core competencies, and core competency skills. Therefore, the design of structured learning (together) is necessary to contribute ideas of the model teacher and peers who the same ancestor, such as learning design patterned LS [2], [10]. Implementation of learning focused on the formation of knowledge, skills, and intelligence of students. Thus, the teacher always is put together the positive attitude to each 
student, resulting in increased capacity/competitiveness for each student. In Figure 1, it provides information on student attitudes after learning by extravagant LS. Compared with students' attitudes before being patterned learning LS (Table 1) and the attitude of the students after learning extravagant given LS, on average, better student attitudes after learning extravagant given LS This allows for pattern be focus LS more attention to students about the formation of knowledge, skills and positive attitudes of students.

Information obtained from Figure 1, there is a development of positive attitudes of students after being patterned learning LS. There are 18 attitudes inherent in every student, all of which have evolved towards the positive. But there are two attitudes that lower development is the honesty and responsibility of students, respectively $59 \%$ and $58 \%$. Therefore, through learning always instilled honesty and a sense of responsibility to the students. Other developments attitude still developed. Focus achievement of learning outcomes extravagant LS is creativity, activeness, cooperation, discipline, responsibility, honesty, and attitudes religious students. The attitude is the basis for students to be able to be a human being smart, competitive, and comprehensive. Therefore, form the character of students able to compete globally.

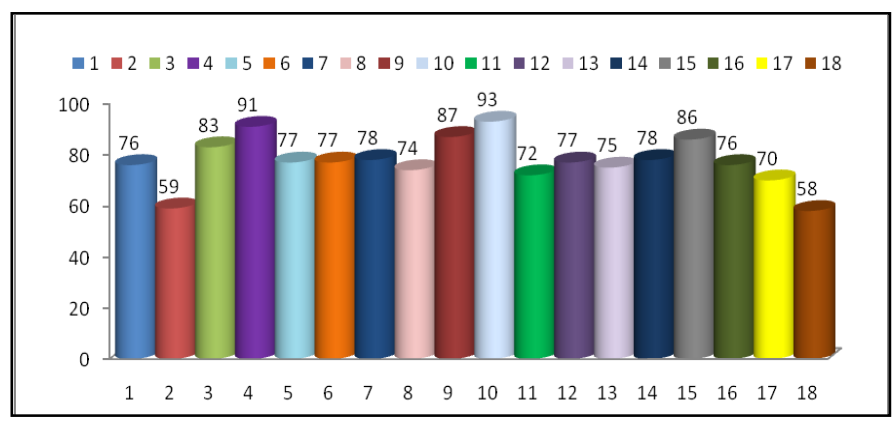

Fig. 1 Presentation of Attitude after LS learning

Factors that influence is to be taught lesson plan (Plan), prepared jointly between teachers (model) with a teacher friend (colleague). Therefore all teachers collaborate on a learning design, inclusion of valuable idea and organizations both related pedagogic material. There are four basic things to consider in making a lesson plan so that its implementation can be successful in the classroom good view, namely; pedagogic character that will be applied, the student's character, the character of the material (principal/sub material discussion), and the facilities that can be prepared to support successful learning [3]. Therefore, the successful implementation of learning is determined by the lesson plan is created.

The second factor influencing the development of positive attitudes of students through LS is the implementation of learning by the model teacher. It has been informed that the focus of concern in implementing the model teacher open class is liveliness, creativity, teamwork, discipline, responsibility, honesty, and planting religious attitude to the students. On this basis, the attitude of students is always progressing. More than that the development of students' attitudes continues to be discussed through the reflection/see to be developed through design/redesign.

Implementation of LS, also instill the skills to each student is the skill of observation, communication, grouping, measurements, conclusions, and predictions creativity. Planting the skills each student will guide students to develop higher level thinking skills. Therefore, learning the LS conducted patterned able to improve the competence of the student's skills. Notice the third picture (Fig. 2)

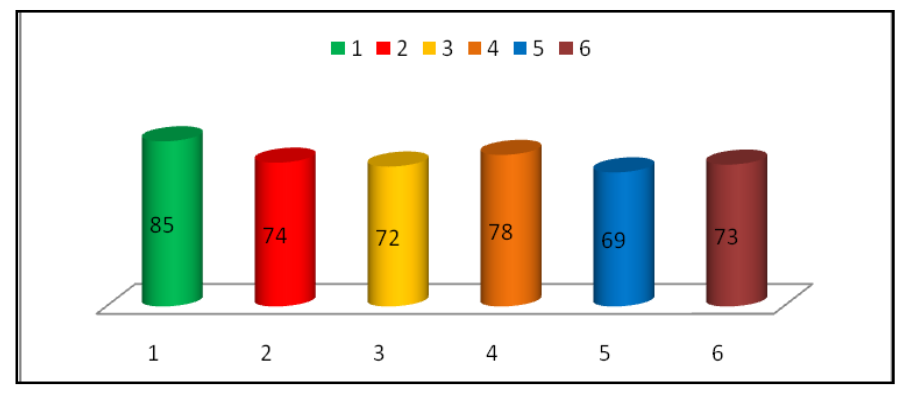

Fig. 2. Presentation of Skill after LS learning

The information can be obtained from Figure 2 that the skill level of the student after being patterned learning LS at an average of above was $70 \%$, except $69 \%$. This means that the LS was able to develop the student's skills. In line with this, the LS was able to develop higher level thinking skills to each student. Why does the country of origin of LS (Japan), while maintaining the pattern of LS, as well as other developed countries adopting the LS from Japan. This forms the competency skills for each student so that students have a high level of intelligence. Results of research conducted by Dyer, 2011, informs that contribute intelligence skills to students is $66.67 \%$, moderate cognitive contributed only $33.33 \%$. It is not surprising that developed countries consistently perform pattern learning LS so that students have a high level of intelligence.

Based on the results of research conducted by TIMSS 2011 on the intelligence level of students around the world, Indonesia was a category of the groups of a low rank of both the sciences and mathematics group. Why is that? this indicates that Indonesian teachers did not make a good plan for implementing the learning in the classroom. Consequently, the intellectual of students formed is low. Application of LS in schools in all regions of Indonesia is still not widely, not continuous and not sustainable. In fact, LS is professional coaching teachers to carry out continuous quality learning continuously. When the learning process is done by qualified teachers (starting from the design and implementation) it will have an impact on improving the quality of student learning outcomes. This is because in the implementation of learning (open class) model teachers apply the three domains, Taxonomy Bloom. 


\section{CONCLUSION}

The pattern of LS learning can improve the professionalism of teachers, therefore, the learning is more qualified. The learning outcomes that conducted by the pattern of LS can improve the character/competence of students such as religious competence, social competence, knowledge competence, and skills competency. As the result, the student can improve student their competence for their intelligent, comprehensive, and competitive.

Recommendation. Every teacher should be used the LS learning in every school by what the pattern-based LS is, at least 2-3 times each semester. Because the LS focuses attention on creativity, liveliness, knowledge, skills and positive attitudes of the student. Therefore, LS can increase the ingenuity and intelligence of students.

\section{ACKNOWLEDGMENT}

Authors would like thanks to Director of Research and Community Service, the Directorate General of Strengthening Research and Development, Ministry of Research, Technology and Higher Education and Head of the Institute for Research and Community Service.

\section{REFERENCES}

[1] J. Dyer, H. Gregersen, and C. M. Christensen, The innovator's DNA: Mastering the five skills of disruptive innovators: Harvard Business Press, 2011.
[2] Ibrahim, "Comparative Study of Learning Implementation Plan (RPP) IPA Master Teacher Lesson Plan Indonesia and Japan.Faculty, Malang.," in National Seminar Lesson Study IV, Universitas Negeri Malang, 2011.

[3] E. Saito, S. Hendayana, H. Imansyah, Ibrahim, K. Isamu, and T. Hideharu, "Development of school-based in-service training under the Indonesian Mathematics and Science Teacher Education Project $\AA$," Improving Schools, vol. 9, pp. 47-59, 2006.

[4] H.Susilo, H. Chotimal, R.Joharmawan, J.umiati, Y. D. Sari, and Sunarjo, School-Based Lesson Study, Master Conservative Towards Innovative Teachers. Malang: Bayu Media Publishing 2009.

[5] Suherman, Supriyadi, S. M. Sabbang, and B. Amri, "Development of Lesson Study in High School Parigi Moutong District and The City of Palu," in The 5th International Conference on Teacher Education: Join Conference State University Singaraja, Singaraja, Bali, Indonesia, 2015.

[6] Ibrahim, "Lesson Study to Improve the Competence of Teachers, the Quality of Learning in Schools and LPTK, as well as its Development in Indonesia," FKIP Universitas Tadulako2012.

[7] P. R. Indonesia, Peraturan Pemerintah Republik Indonesia Nomor 19 Tahun 2005 Tentang Standar Nasional Pendidikan: Departemen Pendidikan Nasional Republik Indonesia, 2005.

[8] Ibrahim, "Learning Model Defining a Comprehensive Strategy Through Science Students Build for the Independence of the Nation," in The National Seminar on Science Education Post Graduate Program, UNS Surakarta, 2012.

[9] S. Hendayana, T. Suratno, A.Supriatna, and F. A. Archipelago, Reflecting on Learning "Practical Experience Lesson Study in Indonesia" Bandung: Risqi PRESS, 2015.

[10] E. K. Kartasasmita, "Role of Teacher Education Institutions in Preparing the Character," presented at The 4th International Conference on Teacher Education: Join Conference UPI and UPSI, Bandung, Indonesia., Bandung, Indonesia, 2010. 